\title{
The Hepatitis C Virus NS2/3 Protease
}

\author{
Sarah Welbourn and Arnim Pause* \\ McGill Cancer Centre and Department of Biochemistry, \\ McGill University, Montreal, Quebec, Canada H3G 1Y6
}

\begin{abstract}
The hepatitis C virus NS2/3 protein is a highly hydrophobic protease responsible for the cleavage of the viral polypeptide between non-structural proteins NS2 and NS3. However, many aspects of the NS2/3 protease's role in the viral life cycle and mechanism of action remain unknown. Based on the recently elucidated crystal structure of NS2, NS2/3 has been proposed to function as a cysteine protease despite its lack of sequence homology to proteases of known function. In addition, although shown to be required for HCV genome replication and persistent infection in a chimpanzee, the role of NS2/3 cleavage in the viral life cycle has not yet been fully investigated. However, several recent studies are beginning to clarify possible roles of the cleaved NS2 protein in modulation of host cell gene expression and apoptosis.
\end{abstract}

\section{Introduction}

The hepatitis $\mathrm{C}$ virus (HCV) is a serious health concern and an important cause of chronic liver disease, leading to cirrhosis and hepatocellular carcinoma in humans (Choo et al., 1989; Hoofnagle, 1997; Kuo et al., 1989). It is estimated that nearly 200 million individuals worldwide are currently infected with $\mathrm{HCV}$. Of particular concern is that the virus establishes a chronic infection in $~ 85 \%$ of cases and that there are no specific and broadly effective antiHCV compounds to date (Hoofnagle, 1997). Belonging to the Flaviviridae family, $\mathrm{HCV}$ is a single-stranded RNA virus of positive polarity that encodes a single polypeptide chain that is cleaved co- and post-translationally into both structural (core, E1, E2, p7) and non- structural (NS2, NS3, NS4A, NS4B, NS5A, NS5B) proteins (reviewed in Reed and Rice, 2000).

The NS2/3 protease is the first of two virally encoded proteases required for $\mathrm{HCV}$ polyprotein processing. Extending from amino acids $810-1206, \mathrm{NS} 2 / 3$ is the first non-structural (NS) protein translated and is responsible for the intramolecular cleavage between NS2 and NS3 (Fig. 1). The amino terminus of NS2 is cleaved from the adjacent $\mathrm{p} 7$ protein by host signal peptidases in a membrane-dependent manner, while the chymotrypsinlike serine protease located in NS3 is responsible for the cleavage at the NS3/4A and downstream junctions. The HCV NS2/3 protein is an autoprotease whose activity is separate from NS3 protease functions. Many studies have focused on the residues and sequences required for efficient NS2/3 processing and it was recently established to function as a novel cysteine protease. Furthermore, although all NS proteins are proposed to play a role in viral replication, the exact functions of $\mathrm{HCV} \mathrm{NS} 2 / 3$, as well as cleaved NS2 remain largely unexplored; however, some interesting potential functions have emerged in recent years. This review will focus on the known properties of the NS2/3 protease as well as the possible functions of both the NS2/3 protease and the NS2 protein.

\section{NS2/3 catalytic cleavage}

\section{General structural features of NS2/3}

The NS2/3 protease is responsible for the intramolecular cleavage of NS2 from NS3 between aa 1026 and 1027 (Grakoui et al., 1993; Hijikata et al., 1993a). Figure 2 shows the main structural and functional domains of the protein. NS2 contains a highly hydrophobic N-terminal region suggested to contain multiple transmembrane segments; however, this region is not required for efficient cleavage at the NS2/3 site (Hijikata et al., 1993a; Pallaoro et al., 2001; Thibeault et al., 2001). The minimal domain for activity of the enzyme has been mapped to aa 907-1206 (Pallaoro et al., 2001). This encompasses the C-terminal portion of NS2, immediately following the hydrophobic region, as well as the $\mathrm{N}$-terminal protease domain of NS3. Although these sequences are required and sufficient for cleavage activity, processing is not dependent on the NS3 serine protease activity (Grakoui et al., 1993; Hijikata et al., 1993a). This differs from the NS2B protein of flaviviruses, in which the NS3 protease performs a cis-cleavage at the NS2B site and then uses NS2B as a co-factor for the processing of the downstream NS polypeptide (Chambers et al., 1991; Chambers et al., 1990; Falgout et al., 1991).

\section{NS2/3 processing requirements}

The HCV NS2/3 protease shows no sequence motifs typical of known proteases; however, sequence alignments show similarity with the GBV NS2/3 protein as well as the bovine viral diarrhea virus (BVDV) NS2/3 protein (Lackner et al., 2004). Residues H952, E972 and C993 are conserved among all genotypes of $\mathrm{HCV}$ and mutation of any of these amino acids to alanine completely inhibits NS2/3 cleavage activity (Grakoui et al., 1993; Hijikata et al., 1993a; Welbourn et al., 2005). Furthermore, although NS3 serine protease activity is not required for NS2/3 processing, the full NS3 protease domain must be present and cannot be substituted for another NS protein (Santolini et al., 1995). In addition, mutation of cysteine residues 1123, 1127 and 1171 in NS3, which together with H1175 participate in the coordination of a zinc molecule (Kim et al., 1996; Love et al., 1996), abolishes both NS3 and NS2/3 activities (Hijikata et al., 1993a), presumably by disrupting folding of the enzymes. This therefore

*For correspondence: arnim.pause@mcgill.ca

(C) Horizon Scientific Press. Offprints from www.cimb.org 


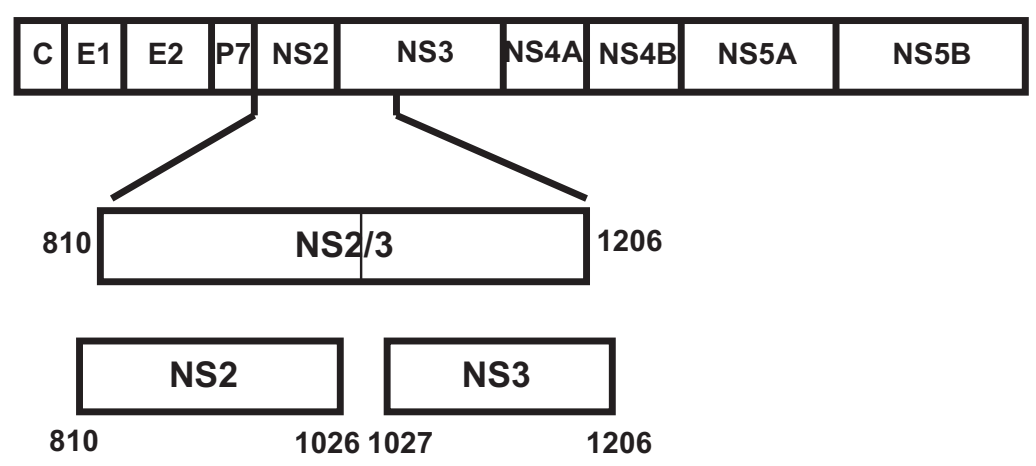

Fig. 1. The HCV NS2/3 protease. The NS2/3 protease is shown in the context of the HCV polyprotein. NS2 and the protease domain of NS3 (from aa 810 to 1206) constitute NS2/3, which undergoes autocatalytic cleavage between aa 1026 and 1027 .

suggests that the NS3 protease domain is required to play a structural role in the folding of the enzyme.

Proper folding of the NS2/3 protein and cleavage site plays an importantrole in the efficiency of NS2/3 processing. Residues surrounding the cleavage site, WRLL $\downarrow$ APIT, are highly conserved between HCV genotypes but are remarkably resistant to mutations (Hirowatari et al., 1993; Reed et al., 1995). Only mutations severely affecting the conformation of the cleavage site (such as deletion or proline substitution of $\mathrm{P} 1$ or $\mathrm{P} 1^{\prime}$ ) severely inhibit cleavage. Furthermore, NS4A-derived peptides that upon binding cause a conformational rearrangement of the NS3 Nterminus are potent inhibitors of NS2/3 activity, likely by altering the positioning of the cleavage site (Darke et al., 1999; Thibeault et al., 2001). The presence of microsomal membranes or non-ionic detergents has been found to be required for in vitro processing at the NS2/3 site in certain genotypes (Pieroni et al., 1997; Santolini et al., 1995), while increasing the efficiency of cleavage of others (Grakoui et al., 1993; Santolini et al., 1995), suggesting the hydrophobic environment is necessary for proper folding of the enzyme and positioning of the cleavage site. Similarly, Waxman et al. have demonstrated the requirement for the ATP hydrolyzing ability of molecular chaperone HSP90 for efficient cleavage in in vitro and cell based assays (Waxman et al., 2001). A similar phenomenon has been described for the BVDV NS2/3 protein where a cellular DnaJ chaperone protein, Jiv, has been found to associate with and modulate NS2/3 activity, possibly by causing a conformational change in the protein (Rinck et al., 2001). Although the mechanisms are still unclear, this could point to a role of cellular chaperones in inducing/maintaining the proper conformation of NS2/3 required for cleavage.

\section{Mechanism of action: a novel cysteine protease}

Initial studies showing NS2/3 activity is inhibited by EDTA and stimulated by zinc led to the early suggestion that $\mathrm{NS} 2 / 3$ functions as a zinc-dependent metalloprotease (Hijikata et al., 1993a). However, with the discovery of the importance of zinc for the structural integrity of the NS3 protease domain, others then proposed NS2/3 may be a novel cysteine protease with a catalytic dyad composed of H952 and C993 with the possible involvement of E972 as the third residue of a catalytic triad. Inhibition studies both in in vitro translation systems and with purified proteins failed to yield a definite classification (Pallaoro et al., 2001; Pieroni et al., 1997; Thibeault et al., 2001). Although inhibited by metal chelators such as phenanthroline and EDTA, this inhibition was relieved by the addition of $\mathrm{ZnCl}_{2}$, $\mathrm{CdCl}_{2}$ or $\mathrm{MgCl}_{2}$. This could therefore point to a structural rather than catalytic role for the zinc molecule as $\mathrm{Cd}$ has not traditionally been able to functionally replace $\mathrm{Zn}$ in other metalloproteases (Angleton and Van Wart, 1988; Cha et al., 1996; Holland et al., 1995). However, although classical cysteine protease inhibitors iodoacetamide and $\mathrm{N}$-ethylmaleimide showed strong inhibition of NS2/3 processing, no single cysteine was found to be more susceptible to these alkylating agents (Pallaoro et al.,

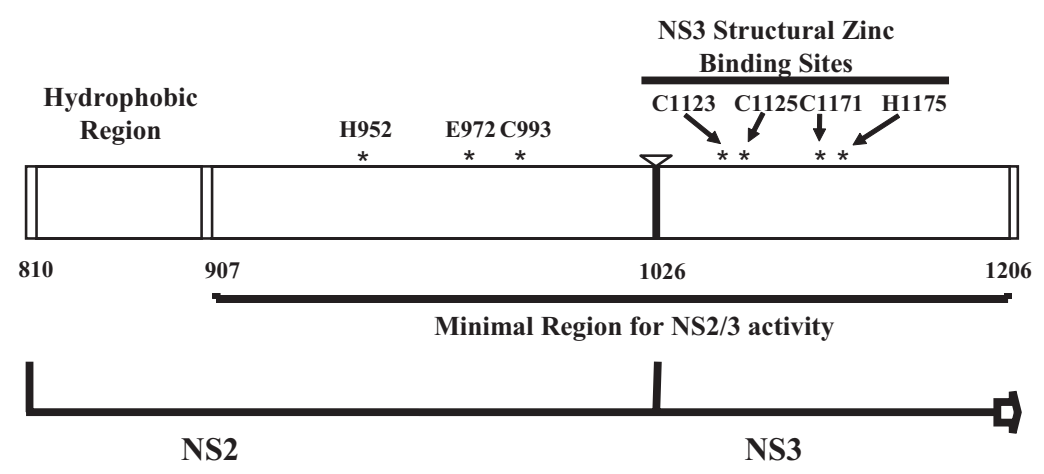

Fig. 2. Functional domains of the NS2/3 protease. The NS2/3 protease encompasses an N-terminal hydrophobic region, with a minimal domain required for activity between aa 907 and 1206. Residues in NS2 required for NS2/3 processing (H942, E972, C993), as well as residues in NS3 responsible for the coordination of a zinc atom are shown. 
2001) and it was only with the recently elucidated crystal structure of its NS2 portion that the enzyme was firmly established as a novel cysteine protease (Lorenz et al., 2006).

Recently, conserved His, Cys and Glu have also been found to be present in BVDV strains and required for NS2/3 cleavage in vitro (Lackner et al., 2004), suggesting a similar mechanism of action of the two proteases. However, several differences exist. In addition to the necessity of the N-terminal hydrophobic region of NS2, BVDV NS2/3 does not require the full NS3 protease domain for activity, but rather possesses a conserved zinc-binding site within NS2 itself (Lackner et al., 2004).

The crystal structure of the N-terminal truncated NS2 portion (aa 904-1026) of the NS2/3 enzyme was recently solved (Lorenz et al., 2006). This structure shows a dimeric enzyme containing two composite active sites. Each active site shows the catalytic histidine and glutamic acid residues present on one monomer with the catalytic cysteine of the triad contributed by the other monomer. As this structure essentially depicts the NS2 cleavage product of the NS2/3 enzyme, it is interesting to note that the $\mathrm{C}$-terminal residues of the protein remain coordinated in the active sites, which was suggested to potentially function to inactivate the protease after cleavage into NS2 and NS3 has occurred.

\section{NS2/3 bimolecular cleavage}

Bimolecular cleavage of $\mathrm{NS} 2 / 3$ has been shown to occur, albeit inefficiently, in cell transfection experiments (Grakoui et al., 1993; Reed et al., 1995). In this system, NS2/3 proteins with mutations/deletions in either the NS2 or NS3 domains could support cleavage provided the missing functional region was co-expressed on a separate polypeptide. In addition, catalytically inactive NS2/3 mutants were also found to inhibit processing of a wildtype protein when expressed in trans. The observation that a recombinant NS2/3 protein forms dimers in vitro was consistent with these findings (Pallaoro et al., 2001). However, no trans cleavage has been observed using purified proteins (Pallaoro et al., 2001; Thibeault et al., 2001). Interestingly, NS2/3 activity in vitro was found to be concentration dependent, supporting the notion that dimer formation is essential for the reaction (Pallaoro et al., 2001). Dimitrova et al. (2003) have also demonstrated the homo-association of the NS2 protein in various systems and suggest that the cleavage between NS2 and NS3 could potentially be performed by dimers of NS2/3 encoded on neighboring polyprotein chains. These observations were recently confirmed by the dimeric crystal structure of NS2 (Lorenz et al., 2006). In addition, co-transfection in mammalian cells of mutant NS2/3 constructs in which either the catalytic cysteine or histidine residues are mutated to alanine, still results in some cleavage of the NS2/3 precursor due to the presence of one functional active site on the dimer (contributed by the cysteine residue on the histidine-mutant monomer and the histidine residue of the cysteine-mutant monomer) (Lorenz et al., 2006). As NS2/3 cleavage was widely believed to be an intramolecular event, the significance of these recent findings with respect to the polyprotein processing events of $\mathrm{HCV}$ infection will be of interest to determine.

\section{Role of NS2/3 cleavage in viral replication}

The role of the NS2/3 protease in HCV replication remains to be fully understood. NS2/3 cleavage is required for viral replication in vivo, as demonstrated by an $\mathrm{HCV}$ clone devoid of NS2/3 activity that fails to cause a persistent infection in a chimpanzee (Kolykhalov et al., 2000). In addition, efficient NS2/3 cleavage is required for replication of the viral RNA genome in a NS2-3-'UTR replicon system (Welbourn et al., 2005). However, NS3-3-'UTR subgenomic replicons not encoding the NS2 protein replicate efficiently in Huh-7 cells (Lohmann et al., 1999), suggesting NS2 itself is not strictly required for genome replication.

If cleavage at the NS2/3 site occurs solely for the release of the NS2 protein, what is the advantage for the virus of encoding two distinct proteases for polyprotein processing? Although several roles have been proposed for the cleaved NS2 protein, the NS2/3 protease itself appears unique in that its activity subsequently causes its inactivation. However, potential regulation of the cleavage reaction could have other implications for the viral life cycle, as is known for BVDV NS2/3 processing. BVDV stains are present in two forms, non-cytopathic (noncp) which expresses primarily uncleaved NS2/3 and has the ability to cause persistent infection and cytopathic (cp) strains expressing cleaved NS3 (Donis and Dubovi, 1987; Pocock et al., 1987). For this pestivirus, RNA replication levels have been shown to correlate with amount of cleaved NS3 protein (Lackner et al., 2004), whereas the uncleaved $\mathrm{NS} 2 / 3$ is required for viral infectivity (Agapov et al., 2004). Evolution of a $\mathrm{cp}$ strain from a non-cp strain occurs through the activation of the NS2/3 cleavage by a variety of mutations, deletions, duplications and rearrangements within the NS2 region (Kummerer et al., 1998; Meyers et al., 1992; Tautz et al., 1996; Tautz et al., 1994). However, it has recently been suggested that BVDV NS2/3 is an autoprotease whose temporal regulation is involved in modulating the different stages of RNA replication and viral morphogenesis (Lackner et al., 2004). Whether HCV NS2/3 could perform a similar regulatory role remains to be determined. It has been shown in the replicon system that mutant, uncleaved NS2/3 is rapidly degraded in cells (Welbourn et al., 2005), which, should regulation of HCV NS2/3 cleavage occur, could potentially be a way for the virus to regulate the levels of the NS3 protein and thus its replication. Although NS2/3 processing appears to be a very efficient event in cell expression systems, the possible role for an uncleaved NS2/3 precursor in the complete viral life cycle has not been ruled out.

\section{NS2 as part of the replication complex?}

HCV RNA replication has been proposed to occur via the formation of a membrane bound replication complex that comprises the association of the NS proteins required for genome replication (NS3-5B). However, as an infectious cell culture system to study the HCV life cycle has only recently been established (Lindenbach et al., 2005, Wakita et al., 2005, Zhong et al., 2005), studies focusing on the replication complex have so far mainly 
used the subgenomic replicon system, where NS2 is not expressed. Several studies have indicated that NS2 is an integral membrane protein that is targeted to the endoplasmic reticulum (ER) (Santolini et al., 1995; Yamaga and Ou, 2002). Interestingly, NS2 has been found by one group to be inserted into the membrane only when expressed in the context of the NS2/3 protein, and only after cleavage from NS3 (Santolini et al., 1995). NS2 has also been found to interact with all other HCV NS proteins in in vitro pull-down, as well as cell-based co-localization and co-immunoprecipitation experiments (Dimitrova et al., 2003; Hijikata et al., 1993b). One group has also directly shown an interaction between NS2 and NS3 using co-immunoprecipitation experiments (Kiiver et al., 2006). Therefore, although not required for RNA replication, the possible presence of NS2 in this complex as an accessory protein is plausible and warrants further investigation.

Interestingly, the recent construction of intergenotypic infectious chimeras containing Con1 (gentotype 1b), $\mathrm{H} 77$ (1a) or J6 (2a) structural proteins in the JFH-1 (2a) backbone, suggests that the optimal junction point of the chimera is within NS2, immediately following the first transmembrane domain (Pietschmann et al., 2006). The most efficient chimeras contained the $\mathrm{C}$-term of NS2 of the same strain as the replicase and the $\mathrm{N}$-term of the same strain as the structural proteins. It is therefore suggested that NS2 may play a dual role in the viral life cycle and in addition to its role in NS2/3 cleavage, may also be involved in virus assembly and release, possibly through association of the N-terminus of NS2 with structural proteins and/or p7. However, the exact mechanisms with which NS2 may be involved in virus assembly and release remain to be determined.

\section{Roles of cleaved NS2}

\section{HCV NS2 is an integral membrane protein}

The NS2 protein derived from the cleavage of NS2/3 is inserted into the ER membrane through its $\mathrm{N}$-terminal hydrophobic domain. However, the exact mechanisms of translocation as well as the membrane topology of the protein remain controversial. Membrane association has been found to be dependent on SRP-SRP receptor targeting (Santolini et al., 1995). It was originally proposed that a signal sequence present in upstream $\mathrm{p} 7$ was required for membrane association co-translationally, although NS2 translocation has subsequently been demonstrated by several groups to be p7 independent (Santolini et al., 1995; Yamaga and Ou, 2002). Furthermore, although the cleavage at the p7-NS2 junction is performed in a membrane-dependent fashion by signal peptidase (Lin et al., 1994; Mizushima et al., 1994) and the presence of membranes is stimulatory (and for some strains required) for NS2/3 cleavage, one group has shown that the integration of NS2 into the membrane is performed post-translationally, and only after cleavage from NS3 (Santolini et al., 1995). However, Yamaga and Ou (2002) have since proposed that translocation could occur cotranslationally and therefore the exact mechanisms of integration remain unclear. The amino terminal region of NS2 is likely to span the membrane several times
(Pallaoro et al., 2001; Yamaga and Ou, 2002). However, the exact number of transmembrane domains, as well as the orientation of the protein in the membrane have not been conclusively determined.

\section{NS2 and NS5A hyperphosphorylation}

$\mathrm{HCV}$ NS5A has many roles in both RNA replication and the modulation of the host cell environment during infection and has been found to be present in two distinct phosphorylated forms: p56 and p58. Liu et al. have reported the importance of NS2 for the generation of hyperphosphorylated NS5A (p58) (Liu et al., 1999). Using plasmids expressing various sections of the HCV polyprotein in transient transfection experiments, they demonstrate the requirement of NS2 generated by the cleavage of $\mathrm{NS} 2 / 3$ for the formation of p58. However, while performing similar experiments, other groups have demonstrated the appearance of p58 without the presence of NS2 (Koch and Bartenschlager, 1999; Neddermann et al., 1999). Indeed, Neddermann et al. (1999) therefore suggested that NS2 itself is not required for the hyperphosphorylation process, but rather that it could be the authentic N-terminus of NS3, generated by $\mathrm{NS} 2 / 3$ cleavage, that is of importance.

\section{NS2 inhibition of gene expression}

NS2 may also play a role in modulating cellular gene expression in infected cells. One study by Dumoulin et al. (2003) found that NS2 exerted a general inhibitory effect on the expression of a reporter gene expressed from a variety of different promoters (human ferrochelatase promoter, NFkappaB binding sites, SV40 promoter/ enhancer sequences, full length, as well as minimal TNFalpha promoters and cytomegalovirus immediate-early promoter) in several different hepatic and non-hepatic cell types. The amino-terminal (810-940) region of NS2 was sufficient to cause this effect, suggesting inhibition of gene expression is not dependent on the activity of the NS2/3 protease itself. It was therefore suggested that NS2 could potentially regulate host cell protein levels by interfering with a general aspect of transcription or translation. Indeed, Kaukinen et al. (2006) have also shown NS2 to inhibit a variety of cellular promoters involved in cytokine gene expression, such as INF- $\beta$, CCL5/RANTES and CXCL10/IP-10 promoters (Kaukinen et al., 2006). Several other HCV-encoded proteins, including core, NS3/4A, NS4B and NS5A, have also been demonstrated to alter cellular gene expression though a variety of mechanisms (Kato et al., 1997; Kato et al., 2000; Naganuma et al., 2000; Ray et al., 1995; Kaukinen et al., 2006). This aspect of NS2 function will require further confirmation and careful investigation as it indicates a potential role for NS2 in the modulation of the host cell environment which has important implications for both the establishment of persistent infection and the pathogenesis of chronic $\mathrm{HCV}$.

\section{NS2 and apoptosis}

In order to establish a persistent infection, many viruses have evolved mechanisms to interfere with cellular apoptosis. In this manner, the virus is then able to replicate to sufficient levels without the elimination of the 
host cell. Several HCV proteins have been implicated in the modulation of cell signaling and apoptosis, including core, E2, NS5A and NS2 (Gale et al., 1997; Honda et al., 2000; Machida et al., 2001; Ruggieri et al., 1997). Machida et al. (2001) have reported that Fas-mediated apoptosis is inhibited in transgenic mice expressing HCV core, E1, E2 and NS2 proteins. The expression of these proteins in the liver prevented cytochrome c release from the mitochondria as well as preventing the activation of caspase 9 and caspase 3/7, but did not affect caspase 8. Therefore, this implicates these HCV proteins in the mitochondrial intrinsic apoptotic pathway, which involves mitochondrial membrane permeabilization and the release of pro-apoptotic factors, resulting in cell death. Furthermore, Erdtmann et al. (2003) showed that NS2 inhibits CIDE-B-induced apoptosis in co-expression experiments. CIDE-B (cell death-inducing DFF45-like effector) is a mitochondrial pro-apoptotic protein whose overexpression has been shown to induce cell death (Inohara et al., 1998). CIDE-B-induced apoptosis requires mitochondrial localization and dimerization of the protein, both of which are mediated by a region in its C-terminal domain (Chen et al., 2000). NS2 was found to interact specifically with the C-terminal region of CIDE-B and block cytochrome $\mathrm{c}$ release from the mitochondria as well as cell death (Erdtmann et al., 2003). NS2 could therefore potentially prevent the dimerization of CIDE-B required for activity. However, the mechanism of inhibition remains unclear as NS2 is thought to be localized at the ER membrane. In this case, NS2 could potentially bind and sequester CIDE-B, preventing its localization at the mitochondria.

Furthermore, expression of the NS2 protein has been shown to inhibit cell proliferation in both transient (Huh-7) and stable (Vero, HeLa) cell assays (Yang et al., 2006). Expression of NS2 was found to be associated with a $40-50 \%$ decrease in the growth rate of the cells, resulting from cell cycle arrest in the S-phase. This was also correlated with a decrease in the levels of cyclin A RNA and protein. Although the mechanisms involved in these observations are currently unknown, it is suggested that NS2 may modify the cell cycle to help provide a cellular environment that is advantageous for viral replication (Yang et al., 2006).

The roles of mature cleaved NS2 remain largely unexplored. Although some possible functions have been proposed and are described here, the use of the newly discovered $\mathrm{JFH}-1$ cell culture system will hopefully help in identifying the main tasks of NS2 in the various events of the viral life cycle. Furthermore, it has been observed that NS2 is a short-lived protein in replicon cells (Franck et al., 2005). Franck et al. (2005) showed that NS2 is a target for phosphorylation by CK2 and is subsequently rapidly degraded by the proteasome. This appears to be a ubiquitin-independent process and the exact mechanisms involved have yet to be identified. However, the regulation of this process could have important implications for the understanding of the various functions of NS2 and the sequential events of the viral life cycle.

\section{Conclusions}

Much work is still required in the study of the NS2/3 protease. Although several studies over the past decade have focused on NS2/3 cleavage, the catalytic mechanism of the enzyme has only recently been established. The three dimensional structure of NS2 provides many insights into the mechanism of action of the enzyme as well as raises interesting questions as to the polyprotein processing events, however it still only represents the post-cleavage form of the protein. How the NS3 portion of the enzyme, and potentially the rest of the yet uncleaved non-structural polyprotein, fits into this model remains an interesting and much more challenging question.

Similarly, a robust cell culture system for the study of the viral life cycle has finally been established (Lindenbach et al., 2005, Wakita et al., 2005, Zhong et al., 2005). Such a system will be crucial to precisely define the roles of NS2/3 cleavage and the NS2 protein in the complete viral life cycle. Of particular interest are the observations that NS2 could potentially modulate the host cell environment during $\mathrm{HCV}$ infection through interference with gene expression and cellular apoptosis. However, it will now be necessary to validate these findings in this more physiologically relevant setting.

NS2/3 cleavage is absolutely required for persistent viral infection in a chimpanzee. The HCV NS2/3 protease shares no obvious sequence homology to any known proteases in the animal kingdom and would therefore make an attractive target for antiviral therapy. The elucidation of the crystal structure of NS2/3, its mechanism of action and precise functions in replication will help to generate important information for the development of strategies for inhibition of NS2/3 processing, which could become the basis for novel HCV therapies in the future.

\section{References}

Agapov, E.V., Murray, C.L., Frolov, I., Qu, L., Myers, T.M., and Rice, C.M. (2004). Uncleaved NS2-3 is required for production of infectious bovine viral diarrhea virus. J. Virol. 78, 2414-2425.

Angleton, E.L., and Van Wart, H.E. (1988). Preparation by direct metal exchange and kinetic study of active site metal substituted class I and class II Clostridium histolyticum collagenases. Biochemistry 27, 74137418.

Cha, J., Pedersen, M.V., and Auld, D.S. (1996). Metal and $\mathrm{pH}$ dependence of heptapeptide catalysis by human matrilysin. Biochemistry 35, 15831-15838.

Chambers, T.J., Grakoui, A., and Rice, C.M. (1991). Processing of the yellow fever virus nonstructural polyprotein: a catalytically active NS3 proteinase domain and NS2B are required for cleavages at dibasic sites. J. Virol. 65, 6042-6050.

Chambers, T.J., Weir, R.C., Grakoui, A., McCourt, D.W. Bazan, J.F., Fletterick, R.J., and Rice, C.M. (1990). Evidence that the $\mathrm{N}$-terminal domain of nonstructural protein NS3 from yellow fever virus is a serine protease responsible for site-specific cleavages in the viral polyprotein. Proc. Natl. Acad. Sci. USA 87, 88988902.

Chen, Z., Guo, K., Toh, S.Y., Zhou, Z., and Li, P. (2000). Mitochondria localization and dimerization are required for CIDE-B to induce apoptosis. J. Biol. Chem. 275, 22619-22622.

Choo, Q.L., Kuo, G., Weiner, A.J., Overby, L.R., Bradley, D.W., and Houghton, M. (1989). Isolation of a cDNA 
clone derived from a blood-borne non-A, non-B viral hepatitis genome. Science 244, 359-362.

Darke, P.L., Jacobs, A.R., Waxman, L., and Kuo, L.C. (1999). Inhibition of hepatitis C virus NS2/3 processing by NS4A peptides. Implications for control of viral processing. J. Biol. Chem. 274, 34511-34514.

Dimitrova, M., Imbert, I., Kieny, M.P., and Schuster, C. (2003). Protein-protein interactions between hepatitis $C$ virus nonstructural proteins. J. Virol. 77, 5401-5414.

Donis, R.O., and Dubovi, E.J. (1987). Differences in virusinduced polypeptides in cells infected by cytopathic and noncytopathic biotypes of bovine virus diarrheamucosal disease virus. Virology 158, 168-173.

Erdtmann, L., Franck, N., Lerat, H., Le Seyec, J., Gilot, D., Cannie, I., Gripon, P., Hibner, U., and GuguenGuillouzo, C. (2003). The hepatitis C virus NS2 protein is an inhibitor of CIDE-B-induced apoptosis. J. Biol. Chem. 278, 18256-18264.

Falgout, B., Pethel, M., Zhang, Y.M., and Lai, C.J. (1991). Both nonstructural proteins NS2B and NS3 are required for the proteolytic processing of dengue virus nonstructural proteins. J. Virol. 65, 2467-2475.

Franck, N., Le Seyec, J., Guguen-Guillouzo, C., and Erdtmann, L. (2005). Hepatitis C virus NS2 protein is phosphorylated by the protein kinase CK2 and targeted for degradation to the proteasome. J. Virol. 79, 27002708.

Gale, M.J., Jr., Korth, M.J., Tang, N.M., Tan, S.L., Hopkins, D.A., Dever, T.E., Polyak, S.J., Gretch, D.R., and Katze, M.G. (1997). Evidence that hepatitis C virus resistance to interferon is mediated through repression of the PKR protein kinase by the nonstructural 5A protein. Virology 230, 217-227.

Grakoui, A., McCourt, D.W., Wychowski, C., Feinstone, S.M., and Rice, C.M. (1993). A second hepatitis C virusencoded proteinase. Proc. Natl. Acad. Sci. USA 90, 10583-10587.

Hijikata, M., Mizushima, H., Akagi, T., Mori, S., Kakiuchi, N., Kato, N., Tanaka, T., Kimura, K., and Shimotohno, K. (1993a). Two distinct proteinase activities required for the processing of a putative nonstructural precursor protein of hepatitis C virus. J. Virol. 67, 4665-4675.

Hijikata, M., Mizushima, H., Tanji, Y., Komoda, Y., Hirowatari, Y., Akagi, T., Kato, N., Kimura, K., and Shimotohno, K. (1993b). Proteolytic processing and membrane association of putative nonstructural proteins of hepatitis $\mathrm{C}$ virus. Proc. Natl. Acad. Sci. USA 90, 10773-10777.

Hirowatari, Y., Hijikata, M., Tanji, Y., Nyunoya, H., Mizushima, H., Kimura, K., Tanaka, T., Kato, N., and Shimotohno, K. (1993). Two proteinase activities in HCV polypeptide expressed in insect cells using baculovirus vector. Arch. Virol. 133, 349-356.

Holland, D.R., Hausrath, A.C., Juers, D., and Matthews, B.W. (1995). Structural analysis of zinc substitutions in the active site of thermolysin. Protein Sci. 4, 19551965.

Honda, A., Hatano, M., Kohara, M., Arai, Y., Hartatik, T., Moriyama, T., Imawari, M., Koike, K., Yokosuka, O., Shimotohno, K., and Tokuhisa, T. (2000). HCV-core protein accelerates recovery from the insensitivity of liver cells to Fas-mediated apoptosis induced by an injection of anti-Fas antibody in mice. J. Hepatol. 33, 440-447.

Hoofnagle, J.H. (1997). Hepatitis C: the clinical spectrum of disease. Hepatology 26, 15S-20S.

Inohara, N., Koseki, T., Chen, S., Wu, X., and Nunez, G. (1998). CIDE, a novel family of cell death activators with homology to the $45 \mathrm{kDa}$ subunit of the DNA fragmentation factor. Embo J. 17, 2526-2533.

Kato, N., Lan, K.H., Ono-Nita, S.K., Shiratori, Y., and Omata, M. (1997). Hepatitis C virus nonstructural region $5 \mathrm{~A}$ protein is a potent transcriptional activator. J. Virol. 71, 8856-8859.

Kato, N., Yoshida, H., Kioko Ono-Nita, S., Kato, J., Goto, T., Otsuka, M., Lan, K., Matsushima, K., Shiratori, Y., and Omata, M. (2000). Activation of intracellular signaling by hepatitis $\mathrm{B}$ and $\mathrm{C}$ viruses: C-viral core is the most potent signal inducer. Hepatology 32, 405-412.

Kaukinen, P., Sillanpaa, M., Kotenko, S., Lin, R., Hiscott, J., Melen, K., and Julkunen, I. (2006). Hepatitis C virus NS2 and NS3/4A proteins are potent inhibitors of host cell cytokine/chemokine gene expression. Virol. J. 3, 66.

Kiiver, K., Merits, A., Ustav, M., and Zusinaite, E. (2006). Complex formation between hepatitis C virus NS2 and NS3 proteins. Virus Res. 117, 264.

Kim, J.L., Morgenstern, K.A., Lin, C., Fox, T., Dwyer, M.D., Landro, J.A., Chambers, S.P., Markland, W., Lepre, C.A., O'Malley, E.T., et al. (1996). Crystal structure of the hepatitis $\mathrm{C}$ virus NS3 protease domain complexed with a synthetic NS4A cofactor peptide. Cell 87, 343355.

Koch, J.O., and Bartenschlager, R. (1999). Modulation of hepatitis $\mathrm{C}$ virus NS5A hyperphosphorylation by nonstructural proteins NS3, NS4A, and NS4B. J. Virol. 73, 7138-7146.

Kolykhalov, A.A., Mihalik, K., Feinstone, S.M., and Rice, C.M. (2000). Hepatitis C virus-encoded enzymatic activities and conserved RNA elements in the $3^{\prime}$ nontranslated region are essential for virus replication in vivo. J. Virol. 74, 2046-2051.

Kummerer, B.M., Stoll, D., and Meyers, G. (1998). Bovine viral diarrhea virus strain Oregon: a novel mechanism for processing of NS2-3 based on point mutations. J. Virol. 72, 4127-4138.

Kuo, G., Choo, Q.L., Alter, H.J., Gitnick, G.L., Redeker, A.G., Purcell, R.H., Miyamura, T., Dienstag, J.L., Alter, M.J., Stevens, C.E., et al. (1989). An assay for circulating antibodies to a major etiologic virus of human non-A, non-B hepatitis. Science 244, 362-364.

Lackner, T., Muller, A., Pankraz, A., Becher, P., Thiel, H.J., Gorbalenya, A.E., and Tautz, N. (2004). Temporal modulation of an autoprotease is crucial for replication and pathogenicity of an RNA virus. J. Virol. 78, 1076510775.

Lin, C., Lindenbach, B.D., Pragai, B.M., McCourt, D.W., and Rice, C.M. (1994). Processing in the hepatitis C virus E2-NS2 region: identification of $\mathrm{p} 7$ and two distinct E2-specific products with different $\mathrm{C}$ termini. J. Virol. 68, 5063-5073.

Lindenbach, B.D., Evans, M.J., Syder, A.J., Wolk, B., Tellinghuisen, T.L., Liu, C.C., Maruyama, T., Hynes, R.O., Burton, D.R., McKeating, J.A., and Rice, C.M. 
(2005). Complete replication of hepatitis C virus in cell culture. Science 309, 623-626.

Liu, Q., Bhat, R.A., Prince, A.M., and Zhang, P. (1999). The hepatitis $C$ virus NS2 protein generated by NS2-3 autocleavage is required for NS5A phosphorylation. Biochem. Biophys. Res. Commun. 254, 572-577.

Lohmann, V., Korner, F., Koch, J., Herian, U., Theilmann, L., and Bartenschlager, R. (1999). Replication of subgenomic hepatitis $\mathrm{C}$ virus RNAs in a hepatoma cell line. Science 285, 110-113.

Lorenz, I.C., Marcotrigiano, J., Dentzer, T.G., and Rice, C.M. (2006). Structure of the catalytic domain of the hepatitis C virus NS2-3 protease. Nature 442, 831835.

Love, R.A., Parge, H.E., Wickersham, J.A., Hostomsky, Z., Habuka, N., Moomaw, E.W., Adachi, T., and Hostomska, Z. (1996). The crystal structure of hepatitis $C$ virus NS3 proteinase reveals a trypsin-like fold and a structural zinc binding site. Cell 87, 331-342.

Machida, K., Tsukiyama-Kohara, K., Seike, E., Tone, S., Shibasaki, F., Shimizu, M., Takahashi, H., Hayashi, Y., Funata, N., Taya, C., et al. (2001). Inhibition of cytochrome $\mathrm{c}$ release in Fas-mediated signaling pathway in transgenic mice induced to express hepatitis C viral proteins. J. Biol. Chem. 276, 12140-12146.

Meyers, G., Tautz, N., Stark, R., Brownlie, J., Dubovi, E.J., Collett, M.S., and Thiel, H.J. (1992). Rearrangement of viral sequences in cytopathogenic pestiviruses. Virology 191, 368-386.

Mizushima, H., Hijikata, M., Tanji, Y., Kimura, K., and Shimotohno, K. (1994). Analysis of N-terminal processing of hepatitis $C$ virus nonstructural protein 2 . J. Virol. 68, 2731-2734.

Naganuma, A., Nozaki, A., Tanaka, T., Sugiyama, K., Takagi, H., Mori, M., Shimotohno, K., and Kato, N. (2000). Activation of the interferon-inducible 2'-5'oligoadenylate synthetase gene by hepatitis $\mathrm{C}$ virus core protein. J. Virol. 74, 8744-8750.

Neddermann, P., Clementi, A., and De Francesco, R. (1999). Hyperphosphorylation of the hepatitis $C$ virus NS5A protein requires an active NS3 protease, NS4A, NS4B, and NS5A encoded on the same polyprotein. J. Virol. 73, 9984-9991.

Pallaoro, M., Lahm, A., Biasiol, G., Brunetti, M., Nardella, C., Orsatti, L., Bonelli, F., Orru, S., Narjes, F., and Steinkuhler, C. (2001). Characterization of the hepatitis C virus NS2/3 processing reaction by using a purified precursor protein. J. Virol. 75, 9939-9946.

Pieroni, L., Santolini, E., Fipaldini, C., Pacini, L., Migliaccio, G., and La Monica, N. (1997). In vitro study of the NS2-3 protease of hepatitis C virus. J. Virol. 71, 6373-6380.

Pietschmann, T., Kaul, A., Koutsoudakis, G., Shavinskaya, A., Kallis, S., Steinmann, E., Abid, K., Negro, F., Dreux, M., Cosset, F.-L., and Bartenschlager, R. (2006). Construction and characterization of infectious intragenotypic and intergenotypic hepatitis $C$ virus chimeras. Proc. Natl. Acad. Sci. USA 103, 7408-7413.

Pocock, D.H., Howard, C.J., Clarke, M.C., and Brownlie, J. (1987). Variation in the intracellular polypeptide profiles from different isolates of bovine virus diarrhoea virus. Arch. Virol. 94, 43-53.
Ray, R.B., Lagging, L.M., Meyer, K., Steele, R., and Ray, R. (1995). Transcriptional regulation of cellular and viral promoters by the hepatitis $\mathrm{C}$ virus core protein. Virus Res. 37, 209-220.

Reed, K.E., Grakoui, A., and Rice, C.M. (1995). Hepatitis C virus-encoded NS2-3 protease: cleavagesite mutagenesis and requirements for bimolecular cleavage. J. Virol. 69, 4127-4136.

Reed, K.E., and Rice, C.M. (2000). Overview of hepatitis $\mathrm{C}$ virus genome structure, polyprotein processing, and protein properties. Curr. Topics Microbiol. Immunol. 242, 55-84.

Rinck, G., Birghan, C., Harada, T., Meyers, G., Thiel, H.J., and Tautz, N. (2001). A cellular J-domain protein modulates polyprotein processing and cytopathogenicity of a pestivirus. J. Virol. 75, 9470-9482.

Ruggieri, A., Harada, T., Matsuura, Y., and Miyamura, T. (1997). Sensitization to Fas-mediated apoptosis by hepatitis C virus core protein. Virology 229, 68-76.

Santolini, E., Pacini, L., Fipaldini, C., Migliaccio, G., and Monica, N. (1995). The NS2 protein of hepatitis C virus is a transmembrane polypeptide. J. Virol. 69, 74617471.

Tautz, N., Meyers, G., Stark, R., Dubovi, E.J., and Thiel, H.J. (1996). Cytopathogenicity of a pestivirus correlates with a 27-nucleotide insertion. J. Virol. 70, 7851-7858.

Tautz, N., Thiel, H.J., Dubovi, E.J., and Meyers, G. (1994). Pathogenesis of mucosal disease: a cytopathogenic pestivirus generated by an internal deletion. J. Virol. 68, 3289-3297.

Thibeault, D., Maurice, R., Pilote, L., Lamarre, D., and Pause, A. (2001). In vitro characterization of a purified $\mathrm{NS} 2 / 3$ protease variant of hepatitis $\mathrm{C}$ virus. J. Biol. Chem. 276, 46678-46684.

Wakita, T., Pietschmann, T., Kato, T., Date, T., Miyamoto, M., Zhao, Z., Murthy, K., Habermann, A., Krausslich, H.G., Mizokami, M., et al. (2005). Production of infectious hepatitis $\mathrm{C}$ virus in tissue culture from a cloned viral genome. Nat. Med. 11, 791-796.

Waxman, L., Whitney, M., Pollok, B.A., Kuo, L.C., and Darke, P.L. (2001). Host cell factor requirement for hepatitis $C$ virus enzyme maturation. Proc. Natl. Acad. Sci. USA 98, 13931-13935.

Welbourn, S., Green, R., Gamache, I., Dandache, S., Lohmann, V., Bartenschlager, R., Meerovitch, K., and Pause, A. (2005). Hepatitis C virus NS2/3 processing is required for NS3 stability and viral RNA replication. J. Biol. Chem. 280, 29604-29611.

Yamaga, A.K., and Ou, J.H. (2002). Membrane topology of the hepatitis C virus NS2 protein. J. Biol. Chem. 277, 33228-33234.

Yang, X.-J., Liu, J., Ye, L., Liao, Q.-J., Wu, J.-G., Gao, J.-R., She, Y.-L., Wu, Z.-H., and Ye, L.-B. (2006). HCV NS2 protein inhibits cell proliferation and induces cell cycle arrest in the S-phase in mammalian cells through down-regulation of cyclin A expression. Virus Res. 121, 134.

Zhong, J., Gastaminza, P., Cheng, G., Kapadia, S., Kato, T., Burton, D.R., Wieland, S.F., Uprichard, S.L., Wakita, T., and Chisari, F.V. (2005). Robust hepatitis C virus infection in vitro. Proc. Natl. Acad. Sci. USA 102, 9294 9299. 


\section{Further Reading}

Caister Academic Press is a leading academic publisher of advanced texts in microbiology, molecular biology and medical research. Full details of all our publications at caister.com

- MALDI-TOF Mass Spectrometry in Microbiology Edited by: M Kostrzewa, S Schubert (2016) www.caister.com/malditof

- Aspergillus and Penicillium in the Post-genomic Era Edited by: RP Vries, IB Gelber, MR Andersen (2016) www.caister.com/aspergillus2

- The Bacteriocins: Current Knowledge and Future Prospects Edited by: RL Dorit, SM Roy, MA Riley (2016)

www.caister.com/bacteriocins

- Omics in Plant Disease Resistance Edited by: V Bhadauria (2016) www.caister.com/opd

- Acidophiles: Life in Extremely Acidic Environments Edited by: R Quatrini, DB Johnson (2016) www.caister.com/acidophiles

- Climate Change and Microbial Ecology: Current Research and Future Trend

Edited by: J Marxsen (2016)

www.caister.com/climate

- Biofilms in Bioremediation: Current Research and Emerging Technologies

Edited by: G Lear (2016)

www.caister.com/biorem

- Microalgae: Current Research and Applications Edited by: MN Tsaloglou (2016) www.caister.com/microalgae

- Gas Plasma Sterilization in Microbiology: Theory, Applications, Pitfalls and New Perspectives Edited by: H Shintani, A Sakudo (2016) www.caister.com/gasplasma

- Virus Evolution: Current Research and Future Directions Edited by: SC Weaver, M Denison, M Roossinck, et al. (2016) www.caister.com/virusevol

- Arboviruses: Molecular Biology, Evolution and Control Edited by: N Vasilakis, DJ Gubler (2016) www.caister.com/arbo

- Shigella: Molecular and Cellular Biology Edited by: WD Picking, WL Picking (2016) www.caister.com/shigella

-Aquatic Biofilms: Ecology, Water Quality and Wastewater Treatment

Edited by: AM Romaní, H Guasch, MD Balaguer (2016)

www.caister.com/aquaticbiofilms

- Alphaviruses: Current Biology

Edited by: S Mahalingam, L Herrero, B Herring (2016)

www.caister.com/alpha

- Thermophilic Microorganisms

Edited by: F Li (2015)

www.caister.com/thermophile
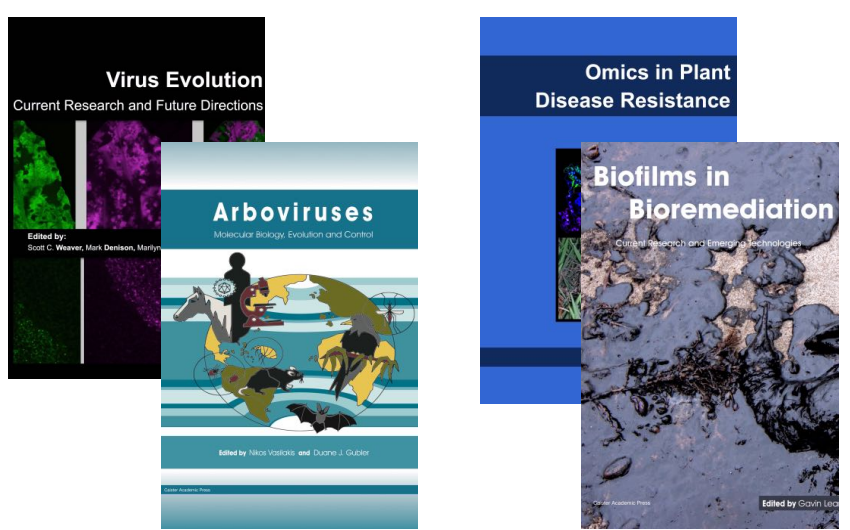
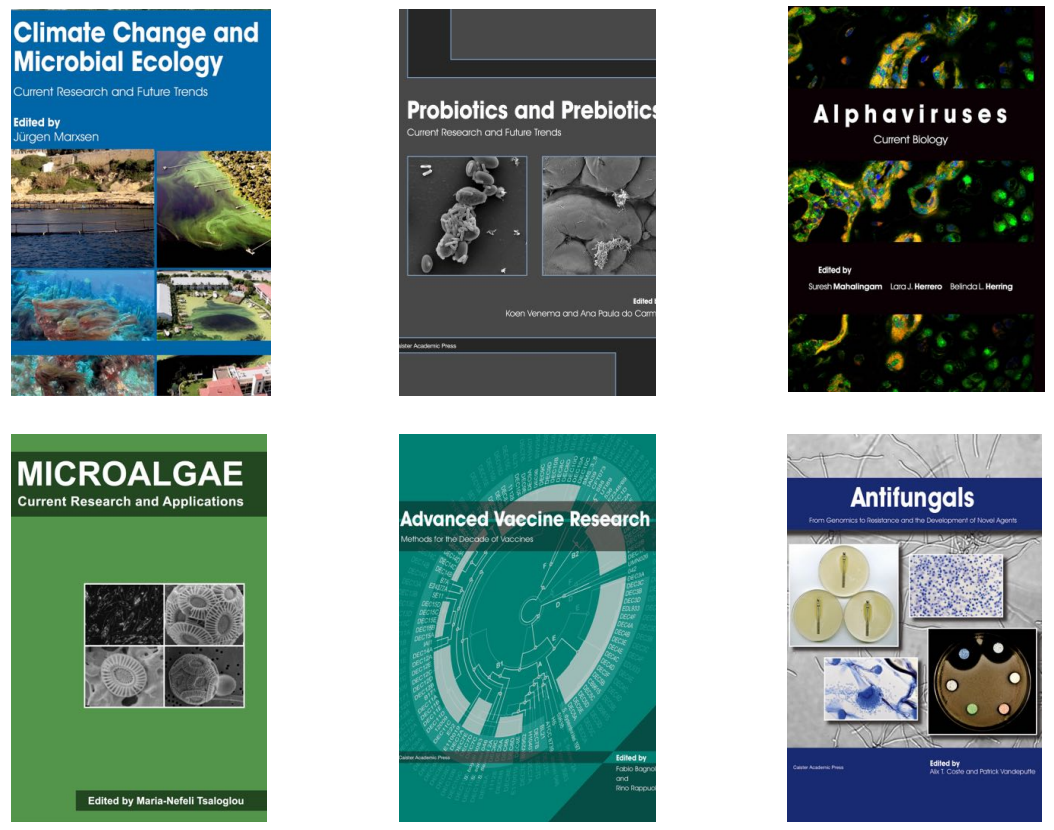

- Flow Cytometry in Microbiology: Technology and Applications Edited by: MG Wilkinson (2015) www.caister.com/flow

- Probiotics and Prebiotics: Current Research and Future Trends Edited by: K Venema, AP Carmo (2015) www.caister.com/probiotics

- Epigenetics: Current Research and Emerging Trends Edited by: BP Chadwick (2015) www.caister.com/epigenetics2015

- Corynebacterium glutamicum: From Systems Biology to Biotechnological Applications

Edited by: A Burkovski (2015)

www.caister.com/cory2

- Advanced Vaccine Research Methods for the Decade of Vaccines

Edited by: F Bagnoli, R Rappuoli (2015)

www.caister.com/vaccines

- Antifungals: From Genomics to Resistance and the Development of Novel Agents

Edited by: AT Coste, P Vandeputte (2015)

www.caister.com/antifungals

- Bacteria-Plant Interactions: Advanced Research and Future Trends Edited by: J Murillo, BA Vinatzer, RW Jackson, et al. (2015) www.caister.com/bacteria-plant

\section{- Aeromonas}

Edited by: J Graf (2015)

www.caister.com/aeromonas

- Antibiotics: Current Innovations and Future Trends

Edited by: S Sánchez, AL Demain (2015)

www.caister.com/antibiotics

- Leishmania: Current Biology and Contro Edited by: S Adak, R Datta (2015) www.caister.com/leish2

- Acanthamoeba: Biology and Pathogenesis (2nd edition) Author: NA Khan (2015)

www.caister.com/acanthamoeba2

- Microarrays: Current Technology, Innovations and Applications Edited by: Z He (2014)

www.caister.com/microarrays2

- Metagenomics of the Microbial Nitrogen Cycle: Theory, Methods and Applications

Edited by: D Marco (2014)

www.caister.com/n2 